pilation of this subject has been made by $\mathbf{K}$. C. Beeson entitled "The Mineral Composition of Crops with Particular Reference to the Soils in which they were grown" (U.S. Dept. Agric. Misc. Pub. No. 369). The question is approached from two main aspects, namely, the soil characteristics associated with nutritional diseases in man and animals, and the various factors which affect the mineral composition of plants. In the first case, bone diseases, anæmias, goitre and selenium poisoning are among the instances discussed, while as regards the crops, fertilizers, ${ }^{\circ}$ climate, irrigation, age and part of the plant are shown to have an important influence on its chemical composition. More than six hundred references are quoted, which cover work carried out in various parts of the world. The publication concludes with extremely useful tables giving the chemical composition of a large number of crops, figures for many of the minor elements being included.

\section{Rediffusion of Broadcasting over Electric Mains}

IN the report of the council of the Incorporated Municipal Electrical Association presented at the annual general meeting at York on June 12, one of the topics raised was broadcasting over the electric mains. In the last annual report it was intimated that in the event of legislation being promoted in this matter, the Association would press for the inclusion of a clause which would authorize electricity undertakers themselves to operate the rediffusion of broadcast programmes over their distributing mains if they so desired. Before the War, the business of rediffusion of broadcast programmes was a growing one and was, for some reason or other, outside the field covered by the electrical industry ; but the Post Office was taking a special interest in the various rediffusion companies. The Electrician of June 13 says that it is probable that the Post Office holds the right to take over such wireless relays if it wishes, and that the further development of broadcasting over the mains might, without adequate protection, become a Government monopoly, with the added privilege of using, without cost to the Post Office, the already existing supply mains, which were put into the roads, etc., after long research and considerable expense by the electrical industry.

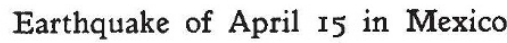

FurTher details are now available concerning the great earthquake which took place on April 15, 1941, in Mexico (see Nature, April 26, 1941, 507). 1t is stated in the news-magazine Time that at the tropical city of Colima, with a population of 20,000, the first shock caused the dam guarding the water supply to collapse, that it disrupted power lines and caused half the buildings in the town to collapse. The cathedral, rebuilt after the earthquake of 1932, was again destroyed, and during the night forest fires blazed round the town due to the scattering of the charcoal burning dumps by the earthquake. At least 36 people in Colima lost their lives. The shock was felt from Jalisco in the north to Oaxaca in the south, while in Mexico City just as lunch time was beginning, towers and signs swayed, church bells tinkled gently, windows rattled and pavements cracked. Mexico's tallest skyscraper, a seventeenstory office building at the corner of the Paseo de la Reforma and the Avenida del Ejido, shook and cracked and a five-story section of glass and facing stone collapsed. Fires broke out, one destroying the El Monte lumberyard after firemen had fought the blaze for six hours. No one was killed in Mexico City though 800,000 dollars worth of damage was done to property. Altogether the earthquake caused near $2,000,000$ dollars worth of damage to property and at least 84 people were killed, including 27 at Tuxpan in the State of Jalisco.

The U.S. Coast and Geodetic Survey, in co-operation with Science Service and the Jesuit Seismological Association, has determined the epic $n$ ntre of this earthquake and its aftershocks from instrumental reports from twenty-one seismographic stations. The epicentre of the first earthquake at $19 \mathrm{~h} .9 \mathrm{~m} .53 \mathrm{~s}$. G.M.T. on April 15 was at lat. $18 \cdot 8^{\circ} \mathrm{N}$., long. $103 \cdot 0^{\circ}$ W., which is some 70 miles south-east of Colima, and the depth of focus normal. Strong aftershocks on April 15 at 23h. 42.6m. G.M.T. and on April 16 at 1h. $37 \cdot 9$ m. G.M.T. had their epicentres slightly north of that of the main shock.

\section{Beit Memorial Fellowships for Medical Research}

Aт a meeting of the Trustees of the Beit Memorial Fellowships for Medical Research held on July 23 it was noted that out of the thirty present fellows thirteen have already been seconded at their own request for more direct service during the War, and that six others have undertaken research work for Government departments on problems arising out of the War.

The following elections of new fellows were made, all with permission for each fellow to be seconded at any time for war duties: Senior Fellowship ( $£ 700$ a year) to Dr. T. R. R. Mann, to continue his work on intracellular metallo-protein compounds, expecially of red blood cells, at the Molteno Institute of Biology, University of Cambridge. Fourth Year Fellowships ( $£ 500$ a year) to Dr. J. F. Danielli, to continue his work on the permeability of muscle fibres and of capil. laries, at the Biochemical Laboratory, University of Cambridge ; Dr. C. O. Hebb, to continue her studies of physiological problems in relation to high altitudes, at the Department of Physiology, University of Edinburgh ; Dr. H. Lehmann, to continue his work on the influence of shock and of the suprarenal glands on glycogen synthesis, at the Biochemical Laboratory, University of Cambridge. Junior Fellowships (normal value $£ 400$ a year) to Dr. E. F. Gale, to study bacterial amine production as a cause of non-specific infantile diarrhœea, at the Biochemical Laboratory, University of Cambridge ; Mr. W. Holmes, to study the regenera. tion of nerve fibres after injury, at the Department of Zoology, University of Oxford ; Dr. M. F. Lockett, to identify renal pressor substances responsible for experimental high blood pressure, at the Pharmacological Laboratory, University of Cambridge. 